\title{
Experimental Investigation on the Effect of Pre-Treatments on Thin Layer Drying and Quality Characteristics of Green Mangoes in Forced Convection Hot Air Drying
}

\author{
Mayank Mishra $^{1 *}$, R.N. Shukla ${ }^{1}$, P. Kandasami ${ }^{2}$ and Boris Huirem ${ }^{3}$ \\ ${ }^{1}$ Department of Food Process Engineering, VSAET, SHIATS, Allahabad-211007, India \\ ${ }^{2}$ Department of Agriculture Engineering, Palli Siksha Bavana, Visva-Bharati, \\ Sriniketan - 731236, India \\ ${ }^{3}$ Food Engineering Department, Bidhan Chandra Krishi Viswavidyala, \\ Mohanpur, West Bengal - 741252, India \\ *Corresponding author:
}

Keywords

Mango (Mangifera indica L.), Aamchur

Article Info

Accepted:

24 May 2019

Available Online:

10 June 2019

\section{A B S T R A C T}

This study investigates the effect of various types of pre-treatments in drying behaviour and quality of slices green mangos in convective drying. This experimental study was carried out with a constant air velocity and thickness $\left(3 \pm 0.5 \times 10^{3} \mathrm{~m}\right)$ of 'dasheri" variety of mangoes, having Julian shape in a laboratory scale dryer at 50,60 and $70^{\circ} \mathrm{C}$ drying air temperatures. Five chemical and one moist heat pre-treatment was done prior to drying to analyse the effect on drying behaviour and quality of final product (aamchur). Dried samples were evaluated for sensory and quality attributes. The result indicates that the citric acid treated samples had highest rehydration ratio while the moist air treated sample have the highest drying rate. According to the result obtained, rehydration ratio was significantly affected by drying air temperature and various pre-treatments have an effect on colour and sensory attributes of the dried products. Effective moisture diffusivity values were calculated using Fick's second law of diffusion and range of calculated values in this experiment was found to be between $2.37 \times 10^{-10}$ to $3.26 \times 10^{-10} \mathrm{~m}^{2} / \mathrm{s}$. and activation energy was $14.7 \mathrm{KJ} / \mathrm{Mol}$. In contrast to industrial practices, drying at higher temperature $\left(70^{\circ} \mathrm{C}\right)$ rather than low $\left(50^{\circ} \mathrm{C}\right.$, for longer period) was optimal for production of 'aamchur'. Since drying time was considerably reduced at elevated temperatures, dryer capacity can be extended.

\section{Introduction}

Mango (Mangifera indica L.) is a major fruit crop of tropics and subtropics, particularly is of Asia and more precisely of India. Where is considered as "king of fruits" (Purseglove,
1972). Currently India is the leading producer of mango in the world with $40 \%$ of world production (the state of food insecurity in world, 2015). In India green mangoes are dried historically to produce 'aamchur', a dried brownish powder for use in seasoning 
and culinary preparations. It is widely used to give a sour and tangy taste to dishes. Traditionally 'aamchur' is used for the preparation of pickle, chutney and sauces etc. (Kesarwani et al., 2000).

The basic objective of drying food product (green mangoes) was the removal of water from fresh product (green mangoes) to reach a level at which microbial spoilage can be avoided (Calin-sanchez et al., 2014).

However, since drying is known as complex process of coupled heat and mass transfer, drying kinetics studies and application of mathematical model to describe drying experimental achieves great practical importance to estimate relevant parameters such as; drying time, mass and thermal diffusivity coefficient, energy consumption among other that are required to develop new food process including products and dryer. However, drying is responsible for many physicochemical and biochemical changes in the processed bio materials.

The advancement of physicochemical and biochemical changes also depends on pretreatments and there level. Pre-treatment quite often proceed with drying operation of fruits and vegetables in order to minimise (or avid) the adverse changes occurring during dehydration and subsequent storage (Abano et al., 2013). The Drying rate can also be improved by pre-treatment's (Dabhade and Khedkar, 1980) (Doymaz, 2004) (Liu, et al., 2014) (Sufer et al., 2017) (Tummanichanont et al., 2017) (Johann et al., 2018) (Serhat Turgut et al., 2018). Also pre-treatment prevent fruit from darkening and colour changes.

Accordingly the principle goal of this study was to assess the effect of pre-treatments on drying kinetics and quality characteristics of mangoes as a strategy to increase the shelf life for reducing post-harvest losses in food supply chain, as well as to consequently add the value.

\section{Materials and Methods}

\section{Material selection and preparation}

First of all, from a local market of Allahabad, India, fresh green mangoes of nearly same dimensions (width, length and breadth) in very good condition was purchased as sample. The samples were washed; drained and other unwanted materials were removed completely. Then these fruits were kept at $4 \pm 2^{\circ} \mathrm{C}$ throughout the experiment. These green mangoes were sliced uniformly in Julian shape with a thick of $3.5 \pm 0.5 \times 10^{-3} \mathrm{~m}$ by using a mango slicer. Original moisture content of these fruit samples was figured out as $507.9027 \%$ (d.b., on an average) by using forced air convection drying.

The sliced green mangoes were divided in seven different segments, and completely randomized design (CRD) was used for the experiment with six pre-treatment, one control and each replicated thrice.

After the slicing, pieces were washed in tap water and samples were drained to remove excess water. Individual lot of 100 g. mangos was subjected to different pre-treatments which are namely;

Moist heat pre-treatment; slices green mango samples were blanched by covering them in muslin cloth and keep it in boiling water for 3 min. Samples were allowed to cool fast by keeping them under flowing(tap) water to prevent over cooking and blotting paper was used to remove excess water.

Chemical pre-treatments; Five different chemical pre-treatments were used. Detail of each pre-treatment along with code name is in table 1. 


\section{Drying kinetics studies}

The pre-treated green mango samples were spreaded uniformly in drying trays in monolayer and placed in a convective hot air dryer. Before the commencement of drying, the dryer was operated for $30 \mathrm{~min}$. to obtain steady state condition prior to drying of samples within the dryer. Samples were subjected to drying at 50,60 and $70^{\circ} \mathrm{C}$ and drying was considered to have ended when two consecutive weights of sample become constant (EMC reached). Hot air orientation in dryer was horizontal over the surface and perforated bottom of drying material. Experiments were carried out in triplicates and sample weights were measured at 5, 10 and $20 \mathrm{~min}$. for first second and subsequent hours during the drying process using a electronic balance of national scales (with accuracy of $\pm 0.01 \mathrm{~g}$. and $600 \mathrm{~g}$ capacity).

\section{Analysis}

\section{Effective moisture diffusivity}

Effective moisture diffusion coefficient $\left(D_{\text {eff }}\right)$ reflects dehydration ability of material under certain drying conditions, and is a significant transport property in modelling of drying process of biological materials, as a function of temperature and moisture content in materials (Doymaz, 2012).

The simplified mathematical Fick's second law of diffusion was used to calculate the effective diffusion coefficient of green mango slices during drying, analytical solution of Fick's second law is given below,

$M R=\frac{8}{\pi^{2}} \sum_{n=0}^{\infty} \frac{1}{(2 n+1)^{2}} \exp \left[-(2 n+1)^{2} \frac{D_{\text {eff } \pi^{2} t}}{4 L^{2}}\right]$

Considering a constant moisture diffusivity, infinite slab geometry and uniform initial moisture distribution;
Where, $D_{\text {eff }}$ is effective diffusion coefficient $\left(\mathrm{m}^{2} / \mathrm{s}\right), \mathrm{L}$ is the half thickness of sample (green mango slices) $(\mathrm{m}), \mathrm{n}$ is the positive integer and $(\mathrm{t})$ is the drying time (s).

\section{Activation energy}

Activation energy (Ea) may define as the necessary work while removing 1 mol water from the material with given moisture content and constant composition. The value of $\mathrm{Ea}$ is an index indicating the bonding potential of moisture in the material (Chen, et al., 2017). Arrhenius equation has been widely used to describe the effect of drying temperature on effective moisture diffusion coefficient to obtain a better fit of the predicted curve with the experimental data (Kashaninejad, Mortazavi, Safekordi, and Tabil, 2007) (Perea-Flores, et al., 2012).

The comparison equation can be written in following form;

$D_{\text {eff }}=D_{\circ} \exp \left(\frac{-E_{a}}{R(T+273.15)}\right)$

A plot of $\ln \left(\mathrm{D}_{\text {eff }}\right)$ against $1 /(\mathrm{T}+273.15)$ produces a straight line graph with $-\mathrm{Ea} / \mathrm{R}$ as the slop and $\ln \left(D_{0}\right)$ as the intercept, from which activation energy and the Arrhenius constant were evaluated. Where, $\left(D_{0}\right)$ is diffusivity coefficient equivalent to diffusivity at infinitely high temperature, $\mathrm{Ea}$ is the activation energy of green mange slices in ( $\mathrm{kJ} / \mathrm{Mol}), \mathrm{R}$ is universal gas constant and $\mathrm{T}$ is drying temperature.

\section{Rehydration ratio}

Rehydration ratio is the measure of food material to reabsorb moisture after being dehydrated. The rehydration characteristics of the dried material were always used as an index of structure quality and is largely 
depends on the dehydration conditions employed (Vishwanathan et al., 2010).

Rehydration ratio $=\frac{\mathrm{B}}{\mathrm{A}}$

Where, B is weight of sample after rehydration and $\mathrm{A}$ is weight of sample before rehydration.

\section{Results and Discussion}

Drying of biological materials shows nonlinear visco-elastic behaviour. To describe the drying behaviour of green mangoes, moisture ratio data is plotted against the drying time and to show the effect of various pretreatments on drying behaviour at particular temperature following graphs are plotted.

\section{Drying characteristics analysis}

The drying curves were obtained by plotting the graph of experimental moisture content against drying time at different temperatures. Effect of different pre-treatments and tray drying temperatures on drying behaviour of green mango slices of same thickness and Julian shape is presented in figure 1,2 and 3. The graphs follow the characteristic curve obtained by (Pal and Khan, 2008), (Rayaguru and Routray, 2012) (Clemente et al., 2014). At the initial stage moisture removal proceeds in exponential manner and then decreases with the time because of higher partial vapour pressure differences between sample and environment, until attain equilibrium moisture content similar results were obtained by (Akhondi et al., 2011) (Kumar et al.,, 2013) (Ponkham et al., 2012) (Shi, et al., 2008).

This was probably due to partial vapour pressure of moisture in sample is initially more in comparison to external environment. The green mango slices were dried at 50, 60 and $70^{\circ} \mathrm{C}$ in forced convection hot air dryer in thin layers of constant thickness. The initial moisture content of sample (on average basis) was about $507 \pm 3 \%$ (d.b.)

Obviously, within temperature range (50 to $70^{\circ} \mathrm{C}$ ), increasing the drying temperature speeds up the drying process, thus shorten the drying time. Similar findings have been reported for drying of other fruits and vegetables (Madamba et al., 1996) (Rayaguru and Routray, 2012) (Chen, et al., 2017).

The moisture ratio versus drying time for green mango slices at selected temperature is shown in figure 1 ( $a, b$ and $c$ ).

The evaluation experimental moisture ratio as a function of drying time of green mango slices at different drying temperatures with different pre-treatments is presented in figure 1. As expected, the MR decreases considerably with an increase in drying time. DT required to reduce the moisture content from initial to EMC at different temperature and pre-treatment on drying time was considerably pronounced which in agreement with other fruit and vegetables such as plums (Goyal et al., 2006), pilchard (Aral and Bese, 2016).

Figure 2, evaluates the DR which presented in amount of water removed from green mango sample at given temperatures. It can be seen at initial drying stages, there was a significant DR difference for different temperature and pre-treatment. Drying rate decreases continuously with an increase in the drying time, similar result for behaviour of DR curve for different fruit and vegetables are obtained by various researchers such as raw olive pomace (Koukouch, et al., 2015).

It can be concluded that the primary loss of moisture was the free water which attaches to the surface of green mango samples and the hydrate water which eliminated in early 
period of drying, whereas, it is difficult to remove the bound water which eliminates at later period. Behaviour of DR versus MC curve is attributed to the less external resistant and higher inner water migration at early stage. Thin layer drying process of green mangoes occurred in falling rate period, which shows that the DR was controlled by internal diffusion phenomenon according to mass transfer controlling process. These results have similarity with the drying of passion fruit peel (Bezerra et al., 2015). From above curve it can also deduce that probably during the drying, the volume and cell gap of green mangoes decreased which resulted in increase of evaporation resistant and decrease in DR.

The changes in DR with MR for different drying temperatures and pre-treatments are shown in figure 3. Data revealed that the DR increases progressively with the MR. experimental result demonstrates the importance of different pre-treatments in reducing the mass transfer resistance of green mango slices. A similar result for effect of pre-treatment has been found for green chillies (Simal et al., 1996).

Table.1 List of chemical pre-treatments with their codes

\begin{tabular}{|l|l|l|l|}
\hline S. No. & Code & Treatment & Description \\
\hline $\mathbf{1}$ & T1 & Ascorbic acid & $\begin{array}{l}\text { 30 g. Powder was mixed with 1L. Water } \\
\text { and sample were kept in solution for } 6 \\
\text { hours. }\end{array}$ \\
\hline $\mathbf{2}$ & T2 & Calcium chloride & $\begin{array}{l}3.5 \%(\mathrm{~W} / \mathrm{W}) \text { Calcium chloride solution } \\
\text { was prepared at } 35^{\circ} \mathrm{C} \text { and samples were } \\
\text { kept in solution for } 8 \text { hours. }\end{array}$ \\
\hline $\mathbf{3}$ & T3 & Citric acid & $\begin{array}{l}\text { Samples were soaked in } 0.3 \% \text { citric acid } \\
\text { solution for } 45 \text { min. }\end{array}$ \\
\hline $\mathbf{4}$ & T4 & Honey & $\begin{array}{l}\text { Samples were dipped in honey for 12 } \\
\text { hours. }\end{array}$ \\
\hline $\mathbf{5}$ & T5 & Sucrose powder & $\begin{array}{l}20 \text { g. sucrose powders was mixed with } \\
100 \text { g. sample and kept in same } \\
\text { condition for } 10 \text { hours. }\end{array}$ \\
\hline
\end{tabular}

Table.2 Effective moisture ratio at different temperatures

\begin{tabular}{|c|c|}
\hline Temperature & Effective moisture diffusivity $\left(D_{\text {eff }}\right)$ \\
\hline $50^{\circ} \mathrm{C}$ & $2.37 \times 10^{-10} \mathrm{~m}^{2} / \mathrm{s}$ \\
\hline $60^{\circ} \mathrm{C}$ & $2.98 \times 10^{-10} \mathrm{~m}^{2} / \mathrm{s}$ \\
\hline $7^{\circ} \mathrm{C}$ & $3.26 \times 10^{-10} \mathrm{~m}^{2} / \mathrm{s}$ \\
\hline
\end{tabular}


Fig.1 Graph of moisture ratio versus drying time at different temperatures

(a)

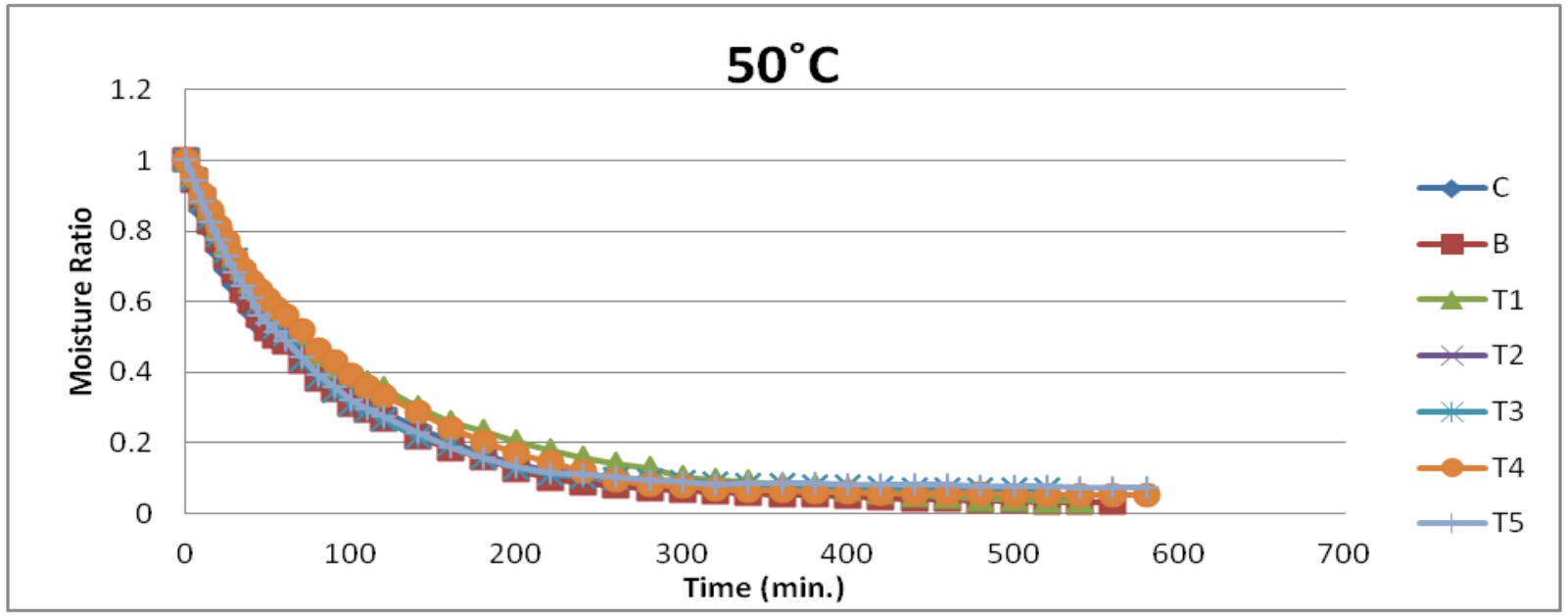

(b)

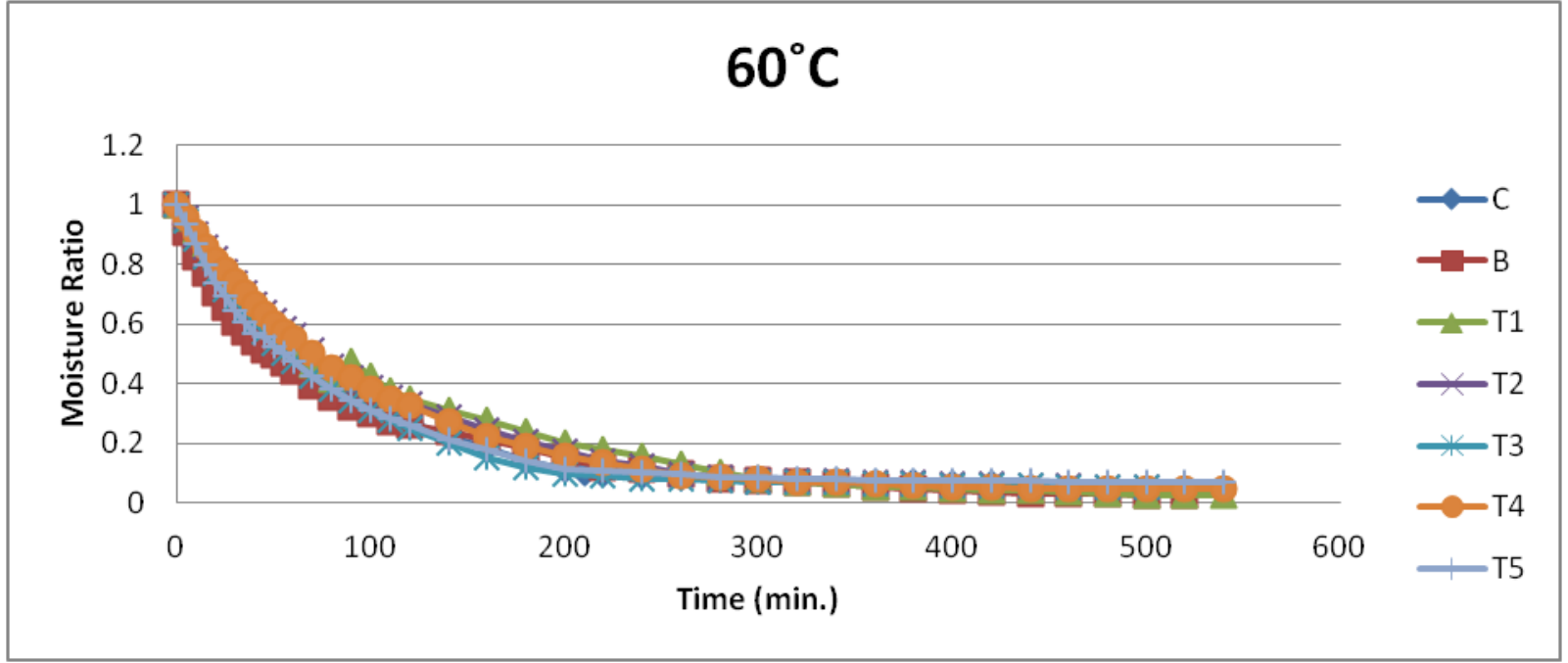

(c)

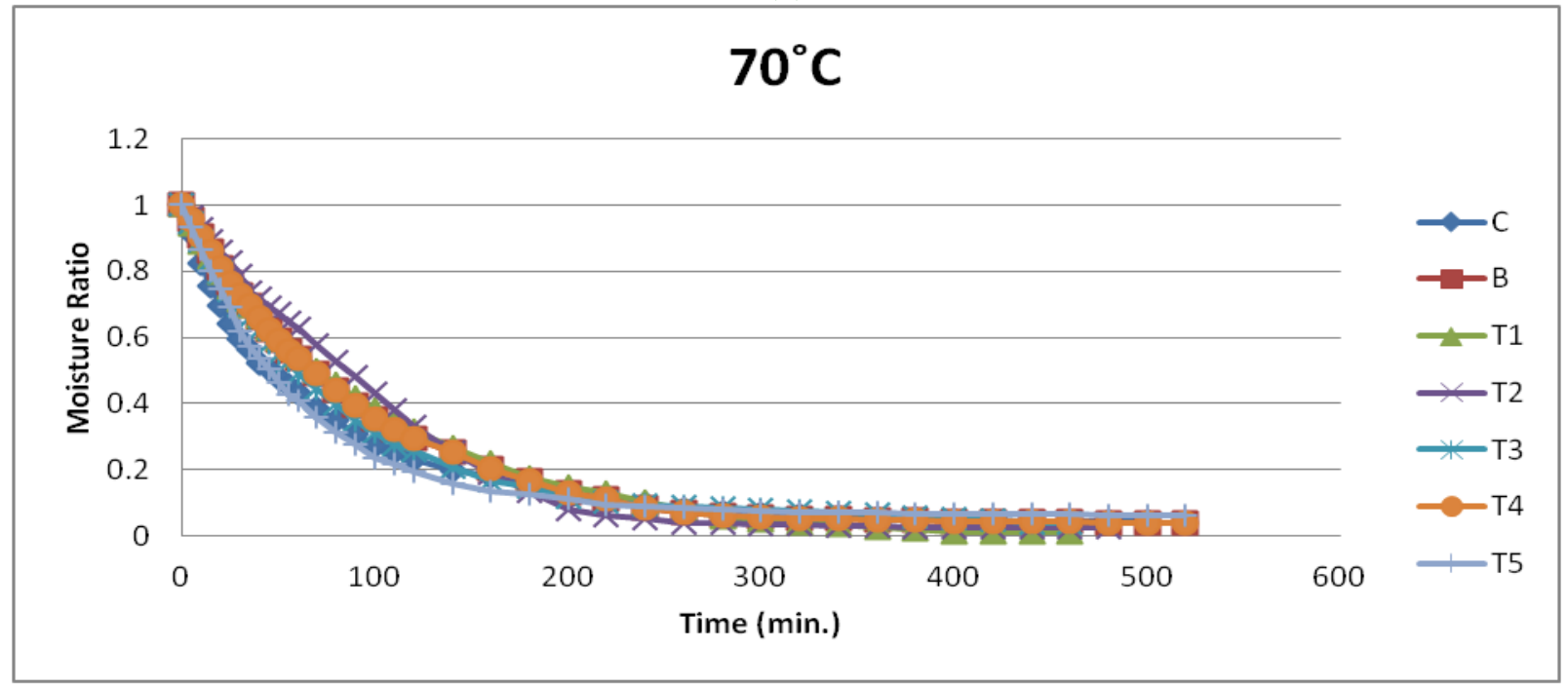


Fig.2 Graph of drying rate versus drying time at different temperatures

(a)

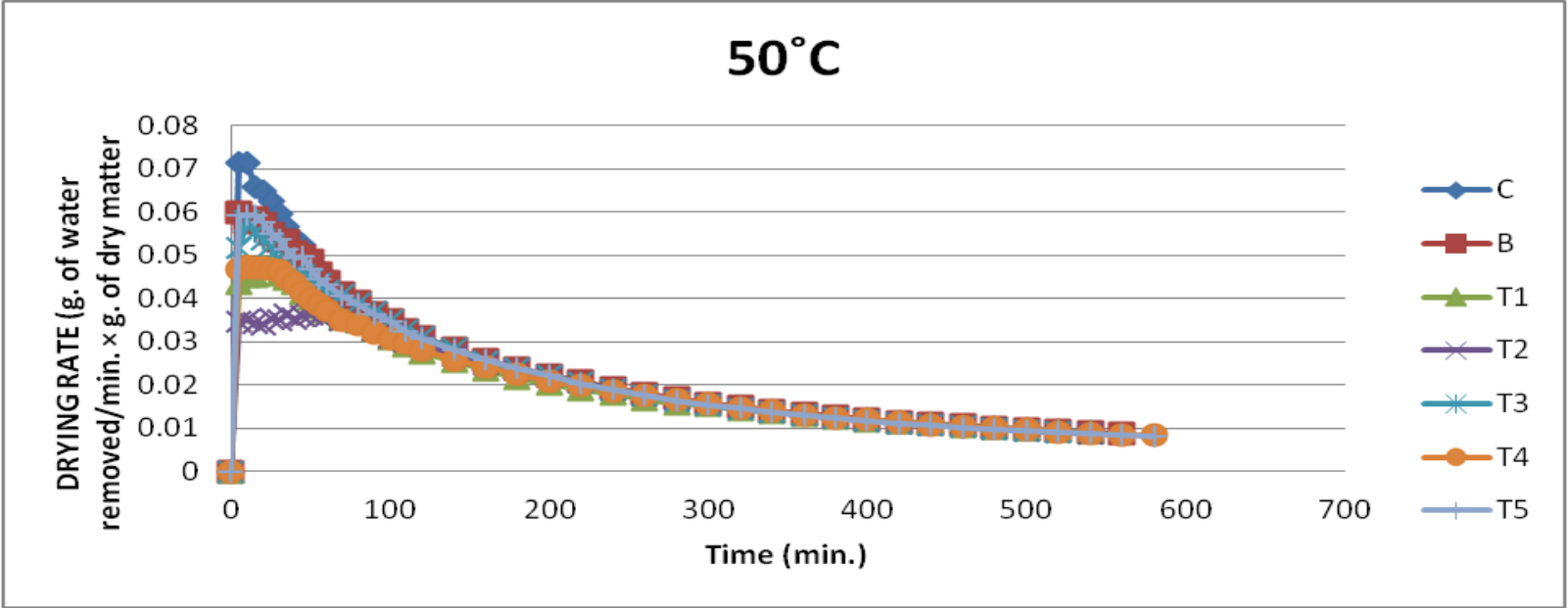

(b)

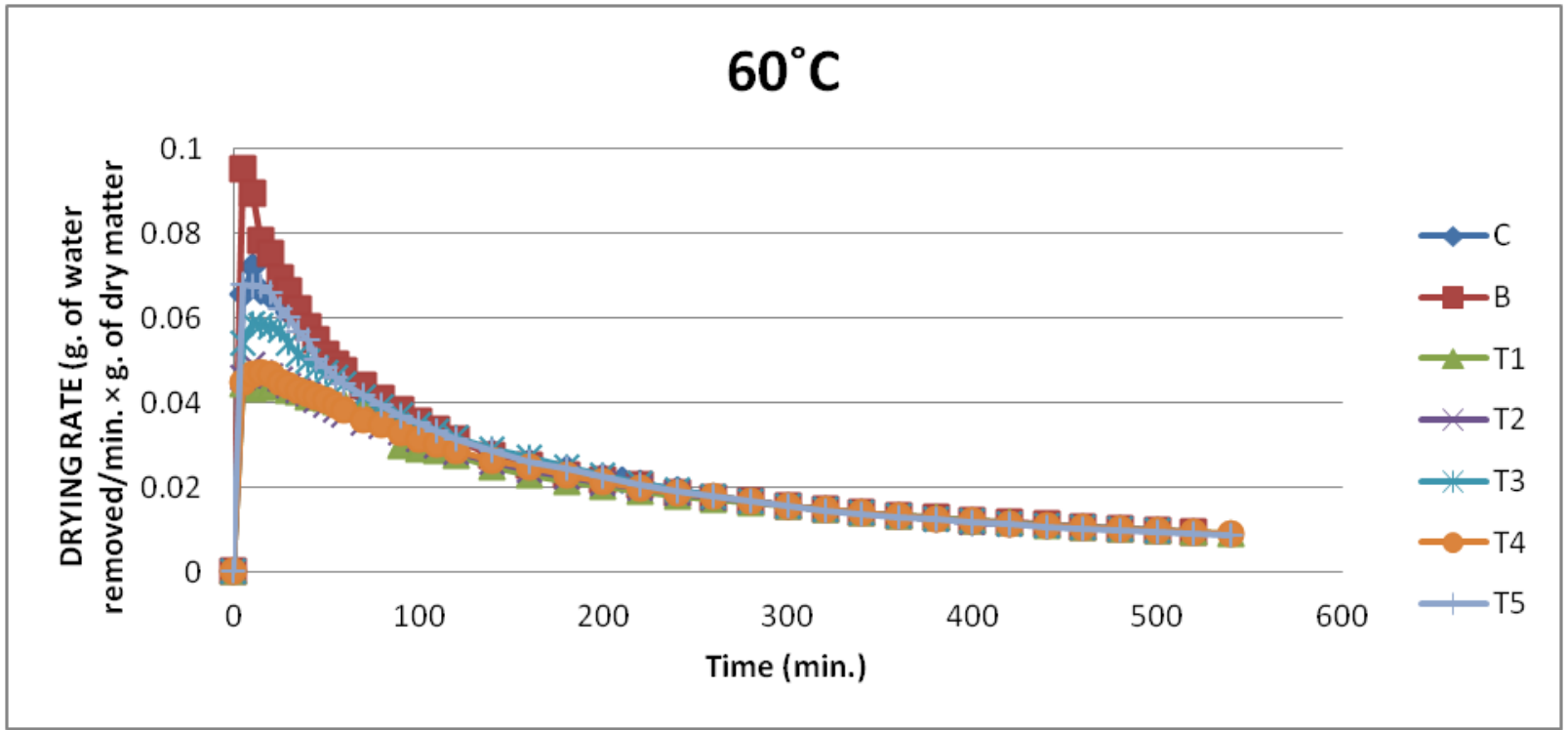

(c)

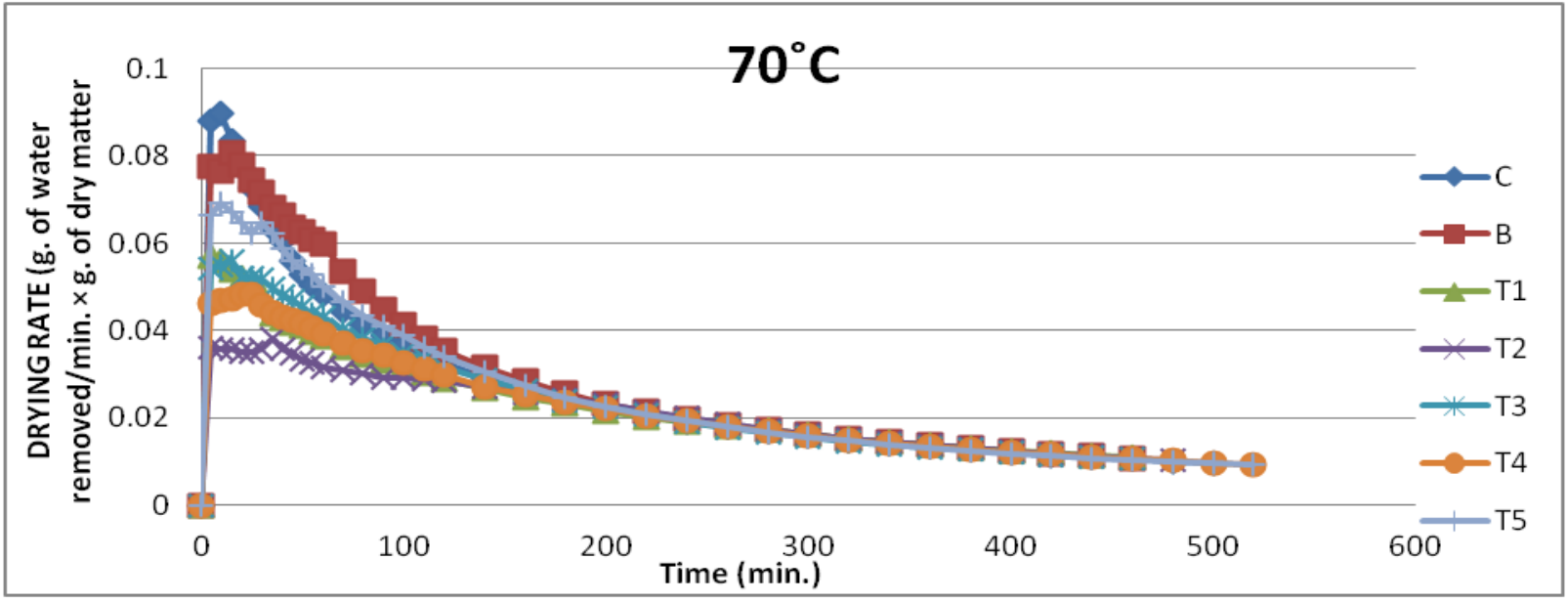


Fig.3 Graph of dying Rate versus Moisture Ratio at different temperatures

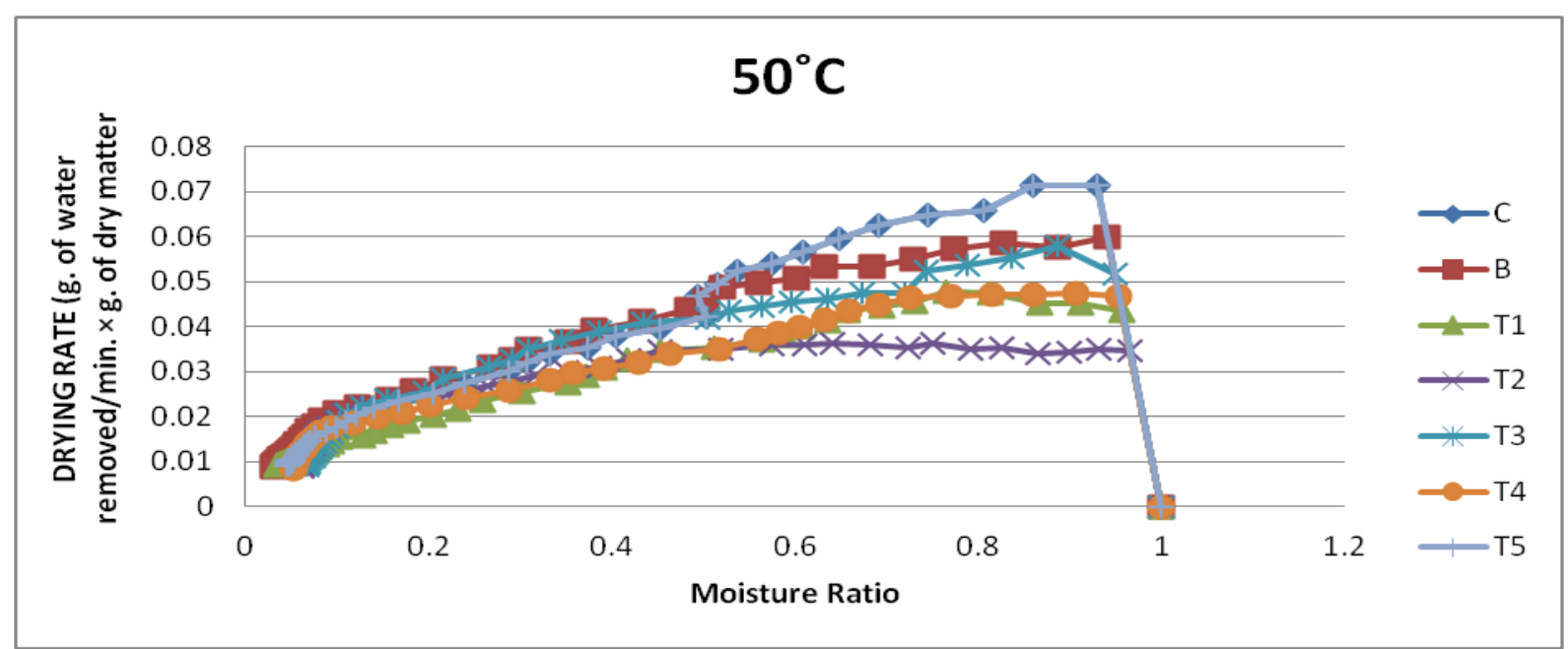

(a)

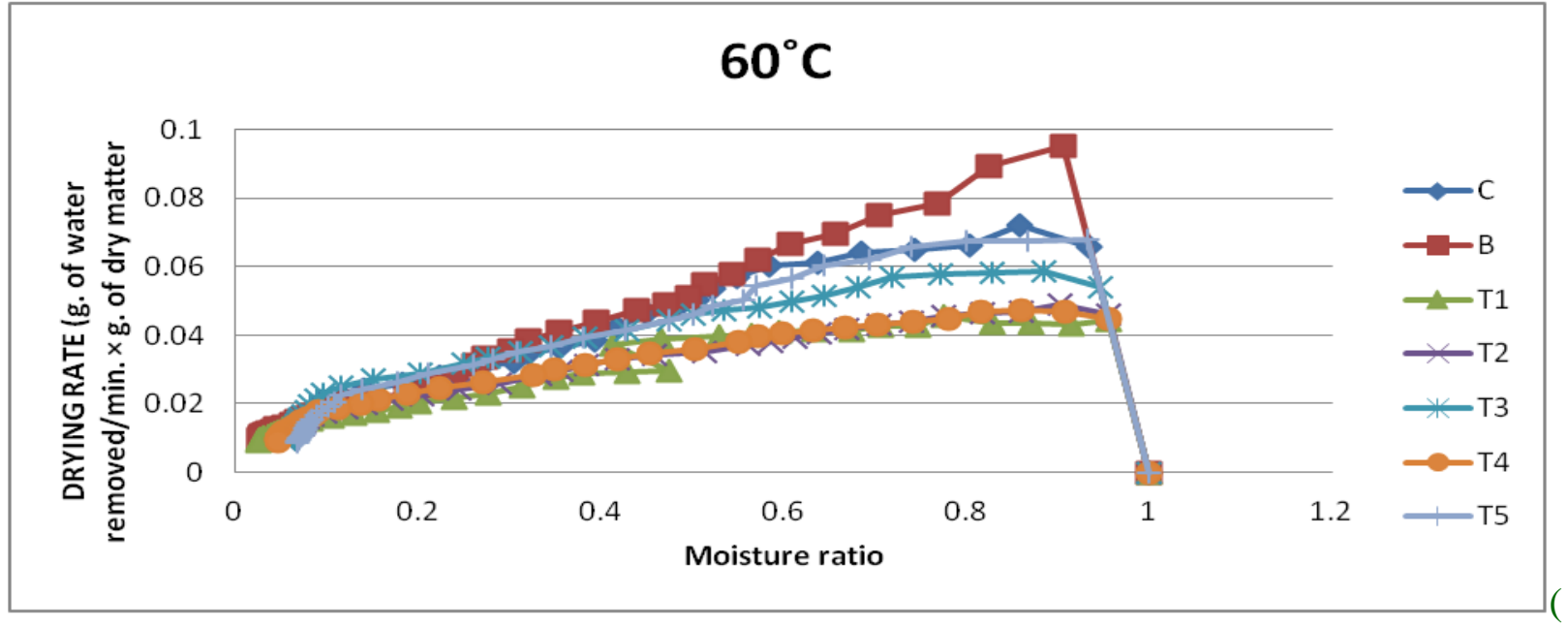

b)

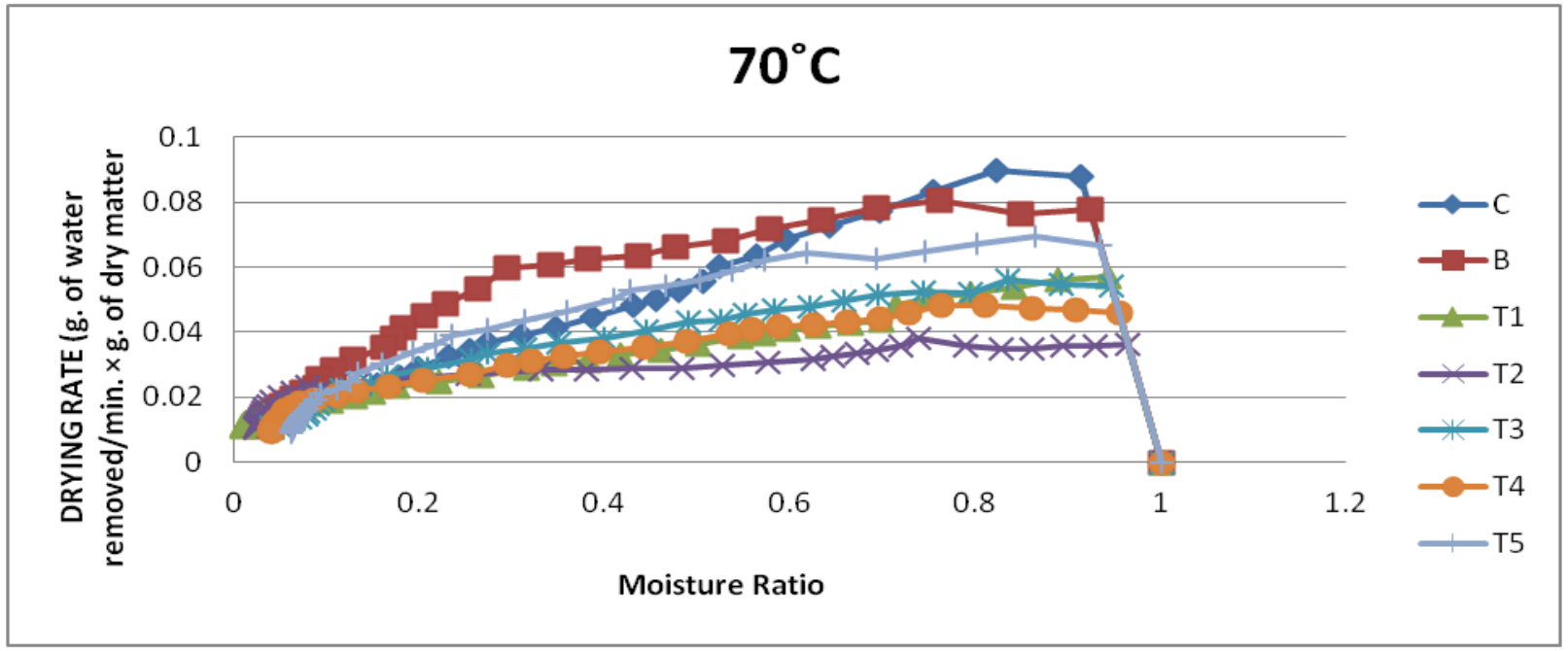

(c) 
Fig.4 Rehydration ratio of green mangoes dried at different temperatures

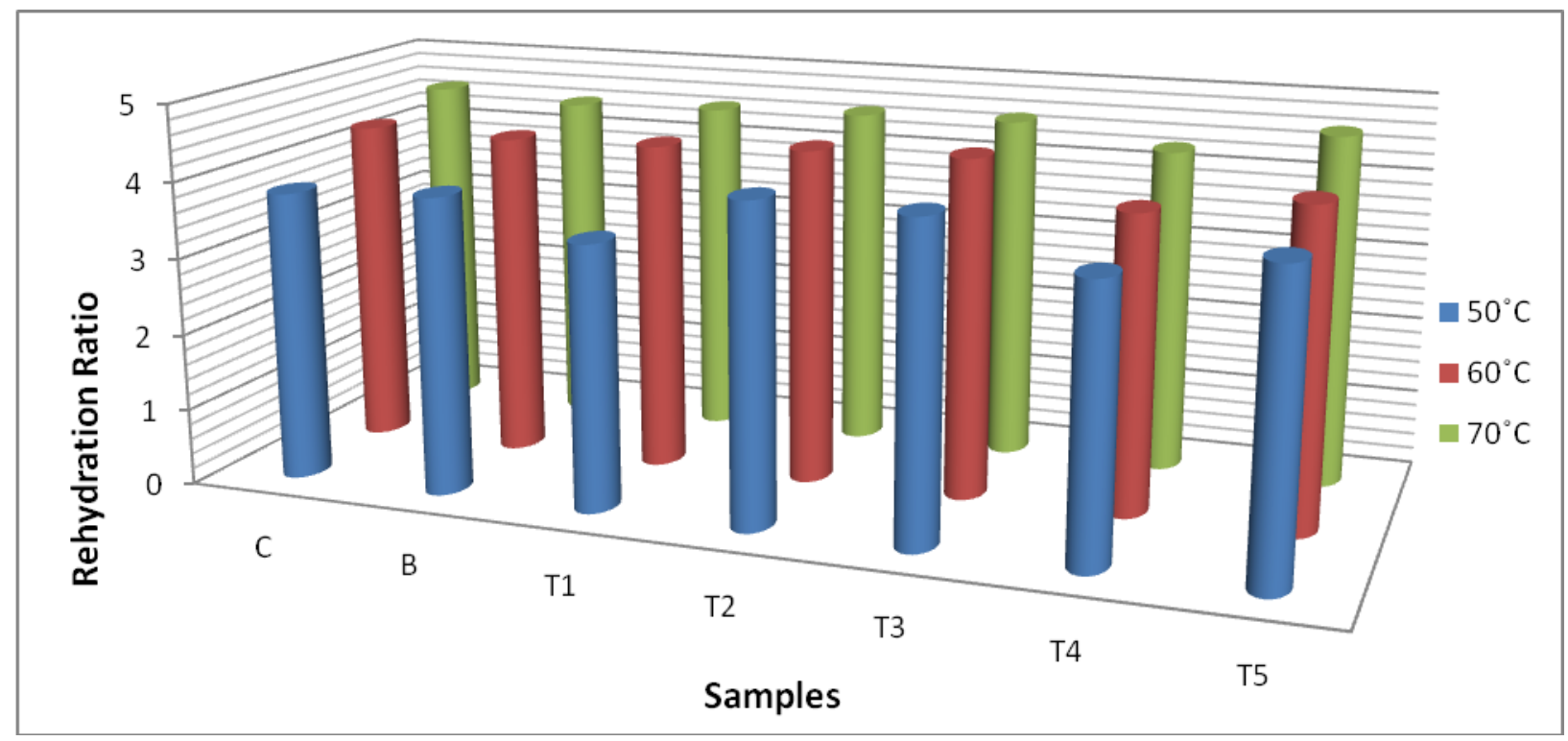

Fig.5 Descriptive analysis profiles of green mangoes for different pre-treatments

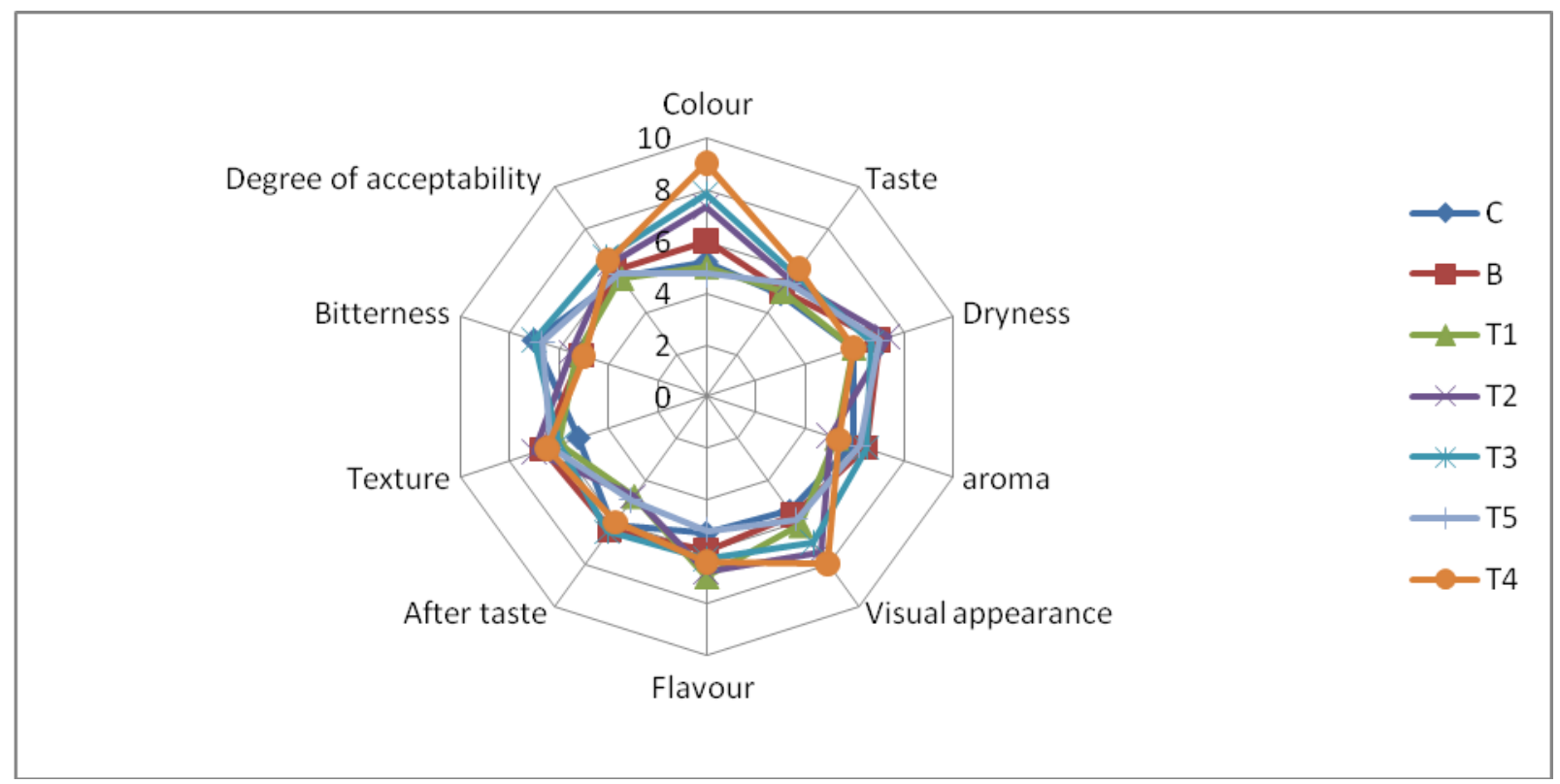

\section{Rehydration ratio}

Rehydration ratio is widely used parameter for dried sample quality. It indicate the physical and biochemical changes during forced convection hot air drying as influenced by processing condition, sample pre-treatment and composition (Feng and Tang, 1998).
Rehydration ratio of dried green mango samples is presented in figure 4. Rehydration ratio of green mango samples affected significantly by drying temperature and pretreatments.

It increases as the drying temperature increases. 
Rehydration at higher temperature was better because of the effect of temperature on cell wall and tissues.

\section{Effective moisture diffusivity and Activation energy}

The values of effective moisture diffusivity of green mango slices for all drying conditions were calculated by Fick's diffusion model (as mentioned above). The determined values for different temperatures are shown in Table 2.

From the above data, it is clear that value of effective moisture diffusivity increases with increasing drying temperature because of increase in vapour pressure within sample. The above values lie in range of $10^{-11}$ to $10^{-9}$ $\mathrm{m}^{2} / \mathrm{s}$, which are general range of moisture diffusivity for food materials (Madamba et al., 1996), (Bablis and Belessiotis, 2004).

The Activation energy value for most food material lies within range of 12.7 to 110 $\mathrm{KJ} / \mathrm{Mol}$, (Zogas et al., 1996). In the present study, Activation energy was found to be 14.7 $\mathrm{KJ} / \mathrm{Mol}$. It is lower than Avishan (Khazaei, et al., 2008), Okra (Doymaz 2005) and onion (Lee and Kim, 2008). Lower the value of activation energy corresponds to ease in movement of water.

\section{Sensory evaluation}

Most significant measure of physical and textural quality of food product is response of human sensory organs to particular food material after processing. Acceptance of processed food material is depends on many sensory attributes such as colour, taste, visual appearance etc. (Fig. 5).

Descriptive sensory evaluation was carried out to determine the effect of pre-treatments on sensory quality attribute of dried green mango samples. Sensory characterisation of sample (aamchur) was done under conditions specified by International ISO Standards. A scoring system using hedonic rating test procedure was used to evaluate and characterise the quality of green mango samples (Tamara, et al., 2014).

A 12 member sensory panel was used to evaluate the various descriptors for colour, texture and taste of samples. Sensory characteristics were scored for degree of liking on 9 point scale from 1 to 9 ( 1 for extremely dislike and 9 for extremely like) score above 5 were considered acceptable.

From the study it may conclude that the faster drying rate was observed in moist heat pretreatment. Moisture ratio studies on mangoes with different pre-treatments revealed that the faster removal of moisture could be achieve with moist heat pre-treatment in forced convection hot air dryer. It was statistically proved that the pre-treatment with honey gave better sensory qualities but rehydration ratio for citric acid treated sample is higher than honey pre-treatment (on average basis). The Activation energy in experiment is calculated as 14.7 $\mathrm{KJ} / \mathrm{Mol}$ and effective moisture diffusivity range between $2.37 \times 10^{-10}$ to 3.26 $\mathrm{X} 10^{-10} \mathrm{~m}^{2} / \mathrm{s}$.

\section{Acknowledgement}

This research was supported by Department of Food Process Engineering, Vaugh School of Agricultural Engineering and Technology, SHUATS, Allahabad.

\section{References}

(2015). the state of food insecurity in world. Food and Agriculture organisation of United Nations. Retrieved from http;//faostat3.fao.org/browser/T/TP/E

Abano, E., Ssam-Amoah, L., Owusu, J., and Engmann, F. (2013). Effect of Ascorbic 
acid, salt, lemon juice and honey on drying kinetics and sensory characteristics of dried mango. Croatian Journal of Food science and Technology, 5(1) 1-10.

Akhondi, E., Kazemi, A., and Maghsoodi, V. (2011). Determination of suitable thin layer drying curve model for saffron (Crocus sativus L.) stigmas in an infrared dryer. Sceintia Iranica, 18, 1397-1401.

Aral, S., and Bese, A. (2016). Convective drying of hawthorn fruit (Crataegus spp.): effect of experimental parameters on drying kinetics, color, shrinkage and rehydration capacity. Food Chem, 210: $577-584$

Bablis, J., and Belessiotis, V. (2004). Influence of th drying conditions on the drying constant and moisture diffusivity during thin layer drying of figs. Journal of Food Engineering, 65, 449-458.

Bezerra, C., Silva, L., Correa, D., and Rodrigues, A. (2015). A modeling study for moisture diffusivities and moisture transfer coefficient in drying of passion fruit peel. International Journal of heat and Mass Transfer, 85, 750-755.

Calin-sanchez, A., Figiel, A., Wojdylo, A., Szaryez, M., and Carbonell-Barrachina, A. (2014). Drying of garlic slices using convective pre-drying and vaccumemicrowave finishing drying: Kinetics, energy consumption and quality studies. Food Bioprocess Technol, 7, 398-408.

Chen, Q., Bi, J., Chen, R., Liu, X., Wu, X., and Zhou, M. (2017). Comparative study on drying characteristics, moisture diffusivity and some physical and nutritional attributes of blanched carrot slices. J Food Processing and Preservation, 41:e13201. doi:https://doi.org/10.1111/jfpp.13201v

Clemente, G., Sanju, N., Arcel, J., and Mulet, A. (2014). Influence of temperature, air velocity and ultrasound application on drying kinetics of grape seed. Drying Technology, $\quad 32(1), \quad 68-76$. doi:https://doi.org/10.1080/07373937.2 013.811592

Dabhade, R., and Khedkar, D. (1980). Studies on drying and dehydration of raw mangoes for prepration of mango powder (amchur): part II: mango drops and their assessment for physicochemical composition. Indian Food Packer, 34(3), 18-31.

Doymaz, I. (2004). Effect of pre-treatments using potassium metabisulphide and alkaline ethyl oleate on the drying kinetics of apricots. Biosystem Engineering, $\quad$ 89(3), 281-287. doi:http://dx.doi.org/10.1007/s11694016-9305-4.

Feng, H., and Tang, J. (1998). Microwave finish drying of diced apples in a spouted bed. Journal of Food Science, 63, 679-683.

Henderson, S., and Perry, R. (1976). Agricultural Process Engineering. New York: III Edition, Wiley.

Johann, G., Menezes, M., Pereira, N., and Da silva, E. (2018). Assessment of pretreatment temperature on the oil extraction from vinification waste. $J$ Food Process and Preservation, e13682. doi:https://doi.org/10.1111/jfpp.13682

Kashaninejad, M., Mortazavi, A., Safekordi, A., and Tabil, L. (2007). Thin layer drying characteristics and modeling of Pastachio Nuts. Journal of Food Engineering, 78-98.

Kesarwani, M., Kohli, U., Raghuvanshi, R. S., and Dwivedi, G. (2000). Quality evaluation of raw mango slices, khatai and mango powder amchur sold in retail market. Journal of Food Science and Technology, 26(12): 1584-1590.

Khazaei, J., Arabhosseini, A., and Khosrobeygi, Z. (2008). Application of superpositiion technique for modeling 
drying behavior of avishan (Zataria multiflora) leaves. Trans. ASABE, 51, 1383-1393.

Koukouch, A., Idlimam, A., asbik, M., Sarh, B., Izrar, B., Bah, A., and Ansari, O. (2015).

Thermophysical characterization and mathematical modelling of convective solar drying of raw olive pomace. Energy Conversion and Manage, 99, 221-230.

Kumar, Singh, M., and Singh, G. (2013). Effect of different pre-treatments on quality of mashroom during solar drying. Journal of Food Science and Technology, 50, 165-170.

Lee, J., and Kim, H. (2008). Drying kinetics of onion slice in hot air dryer. Journal of Food Science and Nutrition, 13, 225230.

Liu, L., Wang, Y., Zhao, D., An, K., Ding, S., and Wang, Z. (2014). Effect of carbonic maceration pre-treatment on drying kinetics of chilli (Capscicum ammum L.) flesh and quality of dried product. Food Bioprocess Technology, 7, 25162527.

Madamba, P., Driscoll, R., and Buckle, K. (1996). Thin layer drying characteristic of garlic slice. Journal of Food Engineering, 29, 75-97.

Pal, U., and Khan, M. (2008). Calculation steps for the design of different components of heat pump dryers under constant drying rate condition. Drying Technology, 26: 864-872. doi: 10.1080/07373930802142226

Perea-Flores, M., Garibay-Febles, V., Chanona-perez, J., CalderonDominguez, G., Mendez, J., Palacios-Gonzalez, E., and GutierrezLopez, G. (2012). Mathematical modelling of castor oil seeds (Ricinus communis) drying kinetics in fludized bed at high temperatures. Industrial Crops and Products, 38, 64-71.

Ponkham, K., Messo, N., Soponronnarit, S., and Siriamornpun, S. (2012). Modeling of combined far-infrared radiation and air drying of a ring shaped pineapple with/without shrinkage. Food Bioprod. Proces., 90,155-164.

Purseglove, J. (1972). Mangoes west of india. Acta Horticulture, 24: 207-74.

Rayaguru, K., and Routray, W. (2012). Mathematical modeling of thin layer drying kinetics of stone apple slice. INternational Food Research, 19(4):1503-1510.

Serhat Turgut, S., Kucukoner, E., and Karacabey, E. (2018). Improvements in drying characteristics and qualiy parameter of tomato by carbonic maceration pretreatment. $J$ Food Process and Preservation, 42:e13282. doi:https://doi.org/10.1111/jfpp.13282

Shi, J., Pan, Z., Mchugh, T., Wood, D., Hirscberg, E., and Olson, D. (2008). Drying and quality characteristics of fresh and sugar infused blueberries dried with infrared radiation heating. LWT- Food Science and Technology, 41, 1962-1972.

Simal, S., Mulet, A., Tarrazo, J., and Rossello, C. (1996). Drying models for green peas. Food chemistry, 55(2): 121128.

Sufer, O., Sezer, S., and Demir, H. (2017). Thin layer mthematical modeling of convective, vaccume and microwave drying of intact and brined onion slice. $J$ Food Process and preservation, 41:e13239.

doi:https://doi.org/10.1111/jfpp13239

Tamara, D., PremovicSanja, B., Dimic, I., Olga, F., Radocaj, B., and Dimic, E. (2014). Impact of seed storage time on the quality of cold pressed sunflower oil. Acta Periodica Technologica, 45, 67-77.

Tummanichanont, C., Phoungchandang, S., and Srzednicki, G. (2017). Effect of pretreatments and drying methods on 
drying characteristics and quality attribute of Andrographids paniculata. $J$ Food process and Preservation, 41:e13310. doi:https://doi.org/10.1111/jfpp.13310

Vishwanathan, K., Hebbar, H., and Raghavarao, K. (2010). Hot air assisted infrared drying of vegetables and its quality. Food Science and Technology Research, 16, 381-388.

Zogas, N., Maroulis, Z., and Marinos-Kouris, D. (1996). Moisture diffusivity data compilation in foodstuffs. Drying Technology, 14: 222-225.

\section{How to cite this article:}

Mayank Mishra, R.N. Shukla, P. Kandasami and Boris Huirem. 2019. Experimental Investigation on the Effect of Pre-Treatments on Thin Layer Drying and Quality Characteristics of Green Mangoes in Forced Convection Hot Air Drying. Int.J.Curr.Microbiol.App.Sci. 8(06): 3112-3124. doi: https://doi.org/10.20546/ijcmas.2019.806.371 